\title{
PERILAKU ORGANIZATIONAL CITIZENSHIP BEHAVIOR BERDASARKAN KARAKTERISTIK PEGAWAI DI RUMAH SAKIT
}

\author{
M. Risya Rizki, Ria Chandra Kartika \\ STIKES Yayasan Rumah Sakit Dr Soetomo Surabaya \\ Email: ria@stikes-yrsds.ac.id
}

\begin{abstract}
Human resources are an important aspect of organizational success. In the last three years, outpatient visits at RSIA NUN Surabaya decreased by $5.32 \%$. The results of the identification showed that, one of the causes of the decrease in visits was patient dissatisfaction with the service of the officers. The objectives of this research were analyzing Organizational Citizenship Behavior (OCB) based on characteristics of employees in the hospital. This research is analytic descriptive with cross sectional study design. The samples were 34 employees were selected using purposive sampling. Result of this research showed that employees who had organizational citizenship behavior in the fewer categories were employees who had more than 32 years of age ( $\geq 32$ years) with $77.8 \%$ presentations. Employees who have Organizational Citizenship Behavior (OCB) with fewer categories are employees who have a work period of less than 2 years with $100 \%$ presentation. The conclusion of this study is that employees who are more mature tend to have low OCB. Employees who have a low working period tend to have a low OCB. Therefore, it is important for hospital management to improve relationships between employees through gathering and maximizing employee potential when undergoing training for new employees.
\end{abstract}

Keywords: Organizational Citizenship Behaviour, Employee Characteristic, Health Worker

\begin{abstract}
ABSTRAK
Sumberdaya manusia merupakan aspek penting dalam kesuksesan organisasi. Dalam tiga tahun terakhir kunjungan pasien rawat jalan di RSIA NUN Surabaya mengalami penurunan sebesar $5,32 \%$. Hasil identifikasi menunjukkan bahwa, salah satu penyebab penurunan kunjungan adalah ketidakpuasan pasien terhadap pelayanan petugas. Tujuan penelitian ini untuk menganalisis perilaku Organizational Citizenship Behavior (OCB) dengan karakteristik pegawai di rumah sakit. Penelitian ini adalah penelitian deskriptif desain studi crossectional. Sampel pada penelitian ini berjumlah 34 pegawai dengan menggunakan teknik purposive sampling. Hasil penelitian menunjukkan bahwa pegawai yang memiliki organizational citizenship behaviour kategori kurang adalah pegawai yang memiliki usia lebih dari 32 tahun ( $\geq 32$ Tahun) dengan presentasi 77,8\%. Pegawai yang memiliki Organizational Citizenship Behavior $(O C B)$ dengan kategori kurang adalah pegawai yang memiliki masa kerja kurang dari 2 tahun dengan presentasi $100 \%$. Kesimpulan dari penelitian ini adalah pegawai yang berusia lebih dewasa cenderung memiliki OCB yang rendah. Pegawai yang memiliki masa kerja rendah cenderung memiliki OCB yang rendah. Oleh karena itu, penting bagi manajemen rumah sakit untuk menguatkan hubungan antar pegawai melalui kegiatan gathering dan memaksimalkan potensi pegawai ketika menjalani training pegawai baru.
\end{abstract}

Kata kunci: Organizational Citizenship Behavior, Masa Kerja, Umur, Pegawai Rumah Sakit 


\section{PENDAHULUAN}

Organisasi rumah sakit merupakan organisasi yang unik dan kompleks. Unik karena di rumah sakit terdapat suatu proses yang menghasilkan jasa perhotelan sekaligus jasa medik dalam bentuk pelayanan kepada pasien yang rawat inap maupun yang berobat jalan. Kompleks karena terdapat permasalahan yang sangat rumit di mana rumah sakit merupakan suatu organisasi padat karya dengan latar belakang pendidikan yang berbeda-beda, didalamnya terdapat berbagai macam fasilitas pengobatan, berbagai macam peralatan, dan yang dihadapipun adalah orang-orang yang beremosi labil, tegang emosional, karena sedang dalam keadaan sakit, termasuk keluarga pasien. Di era kompetisi sekarang ini, jumlah rumah sakit terus bertambah. Rumah sakit dituntut untuk dapat bersaing dalam mengikuti perkembangan di dunia kesehatan dan memenuhi kebutuhan kesehatan masyarakat

Sumber daya manusia merupakan salah satu hal terpenting dalam usaha mencapai keberhasilan suatu organisasi. Saat ini, organisasi harus menghadapi berbagai tantangan seperti cara menanggapi perubahan dari eksternal dan menyesuaikan perubahan yang terjadi dengan lingkungan internal organisasi tersebut. Dengan adanya berbagai tantangan yang dihadapi maka pegawai diharapkan mampu menyesuaikan diri dengan perkembangan dan perubahan yang terjadi.
Dalam menghadapi perubahan dan perkembangan, sumber daya manusia berperan aktif sebagai inisiator dan agen perubahan terus menerus demi meningkatkan kemampuan perubahan organisasi. Studi perilaku organisasi menemukakan ada tiga faktor penentu perilaku dalam organisasi yaitu individu, kelompok, dan struktur. Ketiga hal tersebut dipelajari pengaruhnya pada organisasi dengan tujuan untuk menerapkan ilmu pengetahuan guna meningkatkan keefektifan suatu organisasi. Beberapa variabel dependent dalam perilaku organisasi yaitu, produktivitas, absensi, turnover, dan kepuasan kerja, perilaku menyimpang di tempat kerja dan Organizational Citizenship Behavior (OCB). ${ }^{1}$

RSIA NUN Surabaya merupakan salah satu rumah sakit swasta kelas $\mathrm{C}$ yang terletak di Surabaya dengan pelayanan kedokteran spesialis yang terbatas. Berdasarkan hasil studi pendahuluan yang dilihat dari kunjungan pasien rawat jalan, jumlah kunjungan pasien dari tahun 2014, 2015 dan 2016 berturut-turut adalah sebagai berikut: 19.823, 18.775, dan 17.776. Dari data tersebut dapat diketahui bahwa kunjungan pasien rawat jalan di RSIA NUN Surabaya dalam tiga tahun terakhir mengalami penurunan. Pada tahun 2016 terjadi penurunan jumlah kunjungan pasien rawat jalan di Instalasi Rawat Jalan RSIA NUN Surabaya sebesar $5,32 \%$ 
Survey awal menunjukkan bahwa salah satu penyebab penurunan kunjungan adalah rasa ketidakpuasan pasien terhadap pelayanan petugas di RSIA NUN Surabaya yang didapatkan. Berdasarkan hasil wawancara dengan pengguna pelayanan Instalasi Rawat Jalan RSIA NUN Surabaya didapatkan beberapa keluhan pasien seperti petugas kurang tanggap dan ramah dan merasa hasil pengobatan yang dilakukan tidak sesuai dengan harapan pasien. Hal tersebut menunjukkan bahwa adanya permasalahan kinerja pada pegawai Instalasi Rawat Jalan RSIA NUN Surabaya. Penurunan jumlah dan ketidakpuasan pasien Instalasi Rawat Jalan atas pelayanan yang diterima merupakan suatu masalah besar bagi rumah sakit.

OCB juga sering diartikan sebagai perilaku yang melebihi kewajiban formal (extrarole) yang tidak berhubungan dengan kompensasi langsung. Perilaku Organizational Citizenship Behaviour dipercaya dapat menigkatkan kinerja individu dan kinerja tim secara keseluruhan. Oleh karena itu, penting untuk dilakukan analisis terkait Organizational Citizenship Behaviour dilihat berdasarkan karakteristik pegawai.

Tujuan Penelitian ini adalah menganalisis Organizational Citizenship Behaviour berdasarkan karakteristik pegawai. Hasi penelitian ini diharapkan dapat menjadi masukkan terkait manajemen sumber daya manusia di RSIA NUN Surabaya.

\section{METODE PENELITIAN}

Model yang digunakan pada penelitian ini adalah analisis observasional, dengan rancangan penelitian crossectional. Sampel pada penelitian ini berjumlah 34 pegawai dengan menggunakan teknik purposive sampling. Penelitian ini dilakukan dengan tiga tahap, yaitu: Tahap I perencanaan, Tahap II pelaksanaan, dan Tahap III penulisan laporan. Variabel yang diamati dalam penelitian ini adalah karakteristik pegawai dan Organizational Citizenship Behaviour di RSIA NUN Surabaya. Hasil analisis tersebut kemudian digunakan sebagai masukan terkait manajemen sumber daya manusia.

\section{HASIL DAN PEMBAHASAN}

Karakteristik pegawai pada penelitian ini meliputi umur dan Masa Kerja pegawai yang merupakan pegawai RSIA NUN Surabaya.

\section{Karakteristik Pegawai}

Umur dan masa kerja pegawai pada

penelitian ini dapat dilihat pada Tabel 1 berikut:

Tabel 1. Distribusi Umur Pegawai RSIA NUN Surabaya Tahun 2018

\begin{tabular}{|c|c|c|c|}
\hline \multirow{2}{*}{ No } & \multirow{2}{*}{ Umur } & \multicolumn{2}{|c|}{ Jumlah } \\
\hline & & $n$ & $\%$ \\
\hline 1 & $23-26$ Tahun & 10 & 29,4 \\
\hline 2 & 27 - 31 Tahun & 15 & 44,1 \\
\hline 3 & 32 -47 Tahun & 9 & 26,5 \\
\hline & Total & 34 & 100,0 \\
\hline No & Masa Kerja & $\mathrm{n}$ & $\%$ \\
\hline 1 & $32-47$ Tahun & 9 & 26,5 \\
\hline 2 & 3 - 5 Tahun & 12 & 34,3 \\
\hline 3 & $6-12$ Tahun & 12 & 34,3 \\
\hline & Total & 34 & 100,0 \\
\hline
\end{tabular}


Berdasarkan data pada Tabel 1 dapat diketahui sebagian besar $44,1 \%$ pegawai di RSIA NUN Surabaya berada pada rentang umur 27-31 tahun. Sehingga dapat disimpulkan bahwa pegawai di RSIA NUN Surabaya. Pada tabel ini pula diketahui bahwa pegawai memiliki masa kerja 3-5 Tahun adalah sebesar $34,3 \%$. Pegawai yang memiliki usia 6-12 Tahun adalah sebesar 34,3\%.

\section{Organizational Citizenship Behaviour}

Organizational Citizenship Behaviour pegawai di RSIA NUN Surabaya tahun 2018 adalah sebagai berikut:

Tabel 2. Organizational Citizenship Behaviour Pegawai Pegawai RSIA NUN Surabaya Tahun 2018

\begin{tabular}{ccccc}
\hline No & \multicolumn{2}{c}{ Organizational Citizenship } & \multicolumn{2}{c}{ Jumlah } \\
\cline { 3 - 4 } & & Behaviour & n & $\%$ \\
\hline 1 & Kurang & 25 & 73.5 \\
2 & Cukup & 6 & 17.8 \\
3 & Baik & 3 & 8.8 \\
\hline \multicolumn{2}{r}{} & Total & 34 & 100 \\
\hline
\end{tabular}

Berdasarkan Tabel 2 dapat diketahui sebagian besar pegawai RSIA NUN Surabaya memiliki OCB dengan kategori kurang adalah sebesar $73,5 \%$. Pegawai yang memiliki OCB baik adalah sebesar 8,8\%. Hal tersebut menunjukkan bahwa pegawai di RSIA NUN Surabaya masih kurang untuk melakukan pekerjaan diluar pekerjaan inti pegawai (inrole). OCB merupakan perilaku yang bersifat sukarela dan tidak berkaitan secara langsung dengan sistem reward. OCB bukan merupakan tindakan yang terpaksa terhadap hal-hal yang mengedepankan kepentingan organisasi, dan merupakan perilaku individu sebagai wujud dari kepuasan berdasarkan performance, tidak diperintahkan secara formal.

Tabel 3. Penilaian Organization Citizenship Behaviour Perdimensi

\begin{tabular}{llccc}
\hline No & Dimensi OCB & Min & Max & Mean \\
\hline 1 & Altruism & 2,0 & 2,8 & 2.45 \\
2 & Conscientiousness & 2,4 & 2,8 & 2.62 \\
3 & Civic virtue & 1,4 & 3,0 & 1.94 \\
4 & Sportmanship & 1,8 & 2,4 & 2.05 \\
5 & Courtesy & 1,6 & 3,5 & 2.75 \\
\hline
\end{tabular}

\section{Organizational citizenship behaviour} terdiri dari lima dimensi yaitu; Altruism, Conscientiousness, Courtesy, Sportmanship, dan Civic virtue. Berdasarkan Tabel 3 diketahui bahwa variabel civic virtue menjadi variabel yang memiliki penilaian paling rendah. Civic virtue adalah perilaku yang mengindikasikan tanggung jawab pada kehidupan organisasi (mengikuti perubahan dalam organisasi, mengambil inisiatif untuk merekomendasikan perbaikan prosedur kerja dan melindungi sumber yang dimiliki oleh organisasi. Dimensi ini mengarah pada tanggung jawab yang diberikan organisasi kepada seorang untuk meningkatkan kualitas bidang pekerjaan yang ditekuni. Rendahnya civic virtue pegawai menunjukkan bahwa pegawai di RSIA NUN masih kurangnya tanggung jawab pada kehidupan dan keberlangsungan rumah sakit dan takut untuk mengeluarkan pendapat.

Dimensi concientiousness adalah perilaku yang ditunjukkan dengan berusaha melebihi yang diharapkan perusahaan. Perilaku sukarela yang bukan merupakan kewajiban atau tugas 
karyawan. Dimensi ini menjangkau jauh diatas dan jauh kedepan dari panggilan tugas. Dimensi conscientiousness mendapatkan penilaian tertinggi diantara variabel yang lain. Hal tersebut menunjukkan bahwa pegawai di RSIA NUN Surabaya tergerak untuk melakukan pekerjaan sukarela diluar pekerjaan inti mereka.

Organizational Citizenship Behaviour dengan Umur Pegawai di Rumah Sakit

Tabulasi silang antara organizational citizenship behaviour dengan umur pegawai menunjukkan bahwa pegawai yang memiliki organizational citizenship behaviour kurang adalah pegawai yang memiliki usia lebih dari 32 tahun dengan persentasi 77,8\%. Pegawai yang memiliki umur $\geq 32$ Tahun sebesar $77,8 \%$ memiliki OCB Kurang. Sedangkan pegawai yang memiliki umur $\leq 26$ Tahun memiliki OCB Kurang. Sehingga dapat disimpulkan bahwa semakin tua umur pegawai, maka semakin kurang perilaku karyawan untuk melakukan extra role diluar tugas utama mereka.

Tabel 4. Tabulasi Silang Umur dengan Organizational Citizenship Behaviour

\begin{tabular}{|c|c|c|c|c|c|c|c|c|}
\hline \multirow{3}{*}{ Umur } & \multicolumn{6}{|c|}{ Organizational Citizenship Behaviour } & \multirow{2}{*}{\multicolumn{2}{|c|}{ Total }} \\
\hline & \multicolumn{2}{|c|}{ Kurang } & \multicolumn{2}{|c|}{ Cukup } & \multicolumn{2}{|c|}{ Baik } & & \\
\hline & $\mathrm{n}$ & $\%$ & $\mathrm{n}$ & $\%$ & $\mathrm{n}$ & $\%$ & $\mathrm{n}$ & $\%$ \\
\hline$\leq 26$ Tahun & 7 & 70,0 & 2 & 20,0 & 1 & 10,0 & 10 & 100,0 \\
\hline 27-31 Tahun & 11 & 73,3 & 2 & 13,3 & 2 & 13,3 & 15 & 100,0 \\
\hline$\geq 32$ Tahun & 7 & 77,8 & 2 & 22,2 & 0 & 22,2 & 9 & 100,0 \\
\hline
\end{tabular}

Tabulasi silang umur dengan dimensi Altruism menunjukkan bahwa, pada kelompok umur kurang dari 26 tahun memiliki nilai paling tinggi dengan kategori cukup yaitu sebesar 70\%. Menurut Organ (2006), Altruism adalah perilaku sukarela pada karyawan yang memiliki efek membantu orang lain yang spesifik dengan masalah organisasional yang relevan. ${ }^{2}$ Penilaian pada dimensi Altruism yang ada menunjukkan bahwa kelompok umur muda memiliki Altruism lebih tinggi daripada kelompok umur yang lebih tua. Mcdowell (2015) menyatakan bahwa karyawan dengan usia yang lebih muda, lebih mungkin melakukan OCB untuk alasan prososial, sedangkan karyawan yang lebih tua melakukan OCB untuk motif manajemen sehingga menimbulkan kesan yang baik dan positif dalam diri mereka. ${ }^{3}$ Perilaku prososial merupakan perilaku sosial yang positif, konstruktif dan bermakna membantu. Dari pernyataan tersebut, dapat diketahui bahwa kelompok umur muda memiliki nilai Altruism yang lebih tinggi karena melakukan OCB untuk alasan prososial, maka ia akan dengan sukarela membantu dan menolong karyawan lain yang sedang mengalami kesulitan tanpa harus memikirkan kepentingan sendiri. 
Pada dimensi Conscientousness menunjukkan nilai paling tinggi dengan kategori kurang terdapat pada kelompok umur kurang dari 26 tahun sebesar 60\%. Menurut Purnamie (2014), Conscientousness merupakan perilaku yang ditunjukkan dengan berusaha melebihi yang diharapkan perusahaan. ${ }^{4}$ Perilaku sukarela yang bukan merupakan kewajiban atau tugas karyawan. Penilaian pada dimensi Conscientousness menunjukkan bahwa kelompok umur kurang dari 26 tahun memiliki nilai Conscientiousness yang kurang dibanding dengan kelompok umur yang lain. Hasil penelitian ini didukung oleh Akinbode (2011) yang mengemukakan bahwa karyawan senior lebih mungkin untuk melakukan OCB, dan dalam hal ini yaitu OCB Conscientiousness. ${ }^{5}$ Selain itu, Gyeekye \& Haybatollahi (2015) juga menyatakan bahwa para karyawan yang lebih tua menampilkan ketaatan yang lebih kepada organisasi, dan menujukkan loyalitas yang lebih berpartisipasi aktif dalam organisasi. ${ }^{6}$ Dari pernyataan tersebut menunjukkan bahwa karyawan dengan kelompok umur yang lebih matang atau lebih tua memiliki tingkat OCB Conscientiousness yang lebih tinggi daripada karyawan dengan kelompok umur lebih muda, karena dengan ketaatan dan loyalitas karyawan yang lebih maka karyawan dengan kelompok umur yang lebih tua tersebut akan bekerja melebihi yang diharapkan oleh rumah sakit. Hal tersebut dikarenakan pegawai ingin terus memajukan rumah sakit tempatnya bekerja.
Dimensi Civic virtue menunjukkan nilai paling tinggi dengan kategori sangat kurang terdapat pada kelompok umur kurang dari 26 tahun yaitu sebesar $50 \%$. Menurut Organ et al. (2006), Civic virtue yaitu keterlibatan individu dalam suatu aktivitas organisasi dan peduli terhadap kelangsungan hidup organisasi. ${ }^{2}$ Secara sukarela berpartisipasi, bertanggung jawab dan terlibat dalam mengatasi persoalanpersoalan yang dihadapi oleh organisasi. Ia juga aktif mengemukakan gagasan-gagasannya serta melalui pengamatannya pada lingkungan bisnis baik dalam hal ancaman maupun peluang. Penilaian civic virtue menunjukkan bahwa kelompok umur kurang dari 26 tahun memiliki nilai civic virtue yang sangat kurang dibanding kelompok umur yang lain. Hal ini sesuai dengan Mahnaz et al. (2013) dalam penelitiannya mengemukakan bahwa karyawan yang lebih tua memiliki OCB yang lebih tinggi dibandingkan dengan karyawan yang lebih muda. ${ }^{7,8}$ Hal ini dapat terjadi karena karyawan dengan kelompok umur lebih muda cenderung rendah dalam pengalaman kerjanya jika dibandingkan dengan karyawan dengan kelompok umur lebih tua. Selain itu, karyawan dengan kelompok umur lebih tua, lebih stabil dan punya pandangan yang lebih seimbang terhadap kehidupan sehingga tidak mudah mengalami tekanan mental. Maka dari itu, karyawan memberikan kontribusi yang besar terhadap organisasi, salah satunya membantu menyelesaikan persoalan yang dihadapi. 
Pada dimensi Sportmanship menunjukkan nilai paling tinggi dengan kategori cukup yang terdapat pada kelompok umur kurang dari 26 tahun yaitu sebesar $100 \%$. Organ, Podsakoff \& MacKenzie (2006) menyatakan bahwa Sportmanship menunjukkan suatu kerelaan atau toleransi untuk bertahan bekerja pada suatu organisasi atau perusahaan tanpa mengeluh kendati keadaan perusahaan tersebut kurang menyenangkan. ${ }^{2}$ Penilaian menunjukkan bahwa pada kelompok umur kurang dari 26 tahun memiliki nilai Sportmanship yang lebih tinggi dibanding dengan kelompok umur yang lain. Wijono (2014) mengemukakan bahwa banyak karyawan dengan kelompok umur lebih tua cenderung memperoleh kesempatan lebih besar untuk pemenuhan dan aktualisasi diri. ${ }^{9}$ Halitu memungkinkan bagi karyawan dengan kelompok umur lebih tua justru mendapatkan pekerjaan yang lebih baik dibandingkan karyawan dengan kelompok umur yang lebih muda. Kelompok umur yang lebih tua menganggap dirinya memiliki pengalaman dan lebih baik dalam bekerja sehingga apabila ia tidak nyaman bekerja dalam suatu organisasi maka ia akan keluar dari pekerjaan tersebut dan mencari pekerjaan lain. Namun pada karyawan dengan kelompok umur yang masih muda, ia akan lebih mentoleransi situasi yang terjadi dalam organisasi tempat ia bekerja. Hal tersebut dikarenakan karyawan muda merasa membutuhkan pekerjaan dan takut tidak dapat menemukan pekerjaan yang yang lebih baik sehingga ia akan menerima apapun yang dihadapinya dalam bekerja.

Sedangkan pada dimensi Courtesy, menunjukkan nilai paling tinggi dengan kategori kurang terdapat pada kelompok umur lebih dari 32 tahun yaitu sebesar 88,9\%. Purnamie (2014) menyatakan bahwa Courtesy merupakan menjaga hubungan baik dengan rekan kerjanya agar terhindar dari masalahmasalah interpersonal. ${ }^{4}$ Seseorang yang memiliki dimensi ini adalah orang yang menghargai dan memerhatikan orang lain. Penilaian menunjukkan bahwa pada kelompok umur lebih dari 32 tahun memiliki nilai Courtesy yang kurang dibanding dengan kelompok umur lainnya. Griffith (2006) menjelaskan bahwa relasi antar kerja juga dapat mempengaruhi iklim organisasi, kinerja karyawan dan ahirnya dapat berpengaruh pada produktifitas organisasi. ${ }^{10}$ Dari pernyataan tersebut, karyawan dengan kelompok umur yang lebih muda akan membangun hubungan baik antar sesama rekan kerjanya dibanding dengan karyawan dengan kelompok umur yang lebih tua. Karyawan dengan kelompok umur yang lebih muda akan lebih menghindari konflik, agar dapat terus bekerjasama dengan baik oleh rekan kerja yang lebih tua darinya. Beda halnya dengan karyawan yang lebih tua, karena menganggap dirinya senior dan selalu benar. 
Organizational Citizenship Behaviour dengan Masa Kerja Pegawai di Rumah Sakit

Tabulasi Silang Masa Kerja dengan Organizational Citizenship Behaviour menunjukkan bahwa Pegawai yang memiliki Organizational Citizenship Behavior (OCB) dengan kategori kurang adalah pegawai yang memiliki masa kerja kurang dari 2 tahun dengan presentasi $100 \%$. Pegawai yang memiliki masa kerja lebih dari 6 tahun, sebesar $66,7 \%$ memiliki OCB dengan kategori kurang. Sedangkan pegwai yang memiliki masa kerja kurang dari 2 tahun, sebesar 100\% memiliki OCB Kurang. Sehingga dapat disimpulkan bahwa, semakin rendah masa kerja pegawai di rumah sakit maka semakin kurang perilaku karyawan untuk melakukan kegiatan extra role diluar tugas utama mereka.

Hasil tabulasi silang dimensi Altruism pada pegawai dengan Masa Kerja kurang dari 2 tahun memiliki nilai paling tinggi dengan kategori cukup yaitu sebesar $80 \%$. Hasil penelitian ini sesuai dengan pernyataan Sastrohadiwiryo (2005) bahwa makin singkat masa kerja, makin sedikit pengalaman yang diperoleh, ${ }^{11}$ serta pernyataan Bukhori (2009) menyatakan bahwa generasi masa kerja baru merupakan generasi muda yang baru merintis karir. ${ }^{12}$ Dalam generasi ini memiliki karakteristik kreatif, manja dan ambisius. Hal ini menunjukkan bahwa meskipun masa kerja baru tetapi memiliki nilai Altruism yang tinggi karena memiliki jiwa ambisius dalam merintis karir. Selain itu, dalam masa merintis karir mayoritas pegawai akan ambisius untuk menciptakan kesan terbaik dalam pekerjaannya. Berdasarkan dimensi Conscientousness pada pegawai dengan Masa Kerja selama 3-5 tahun memiliki nilai paling tinggi dengan kategori kurang yaitu sebesar $66,7 \%$. Hal ini sesuai dengan penelitian oleh Rinda (2011) yang menyatakan bahwa masa kerja memiliki pengaruh penting dalam memicu munculnya stress kerja. ${ }^{13}$ Dari pernyataan berikut dapat disimpulkan bahwa pegawai dengan masa kerja yang lama akan cenderung merasakan stress dan bosan sehingga memiliki nilai conscientousness yang kurang.

Tabel 5. Tabulasi Silang Masa Kerja dengan Organizational Citizenship Behaviour

\begin{tabular}{|c|c|c|c|c|c|c|c|c|}
\hline \multirow{3}{*}{ Masa Kerja } & \multicolumn{6}{|c|}{ Organizational Citizenship Behaviour } & \multirow{2}{*}{\multicolumn{2}{|c|}{ Total }} \\
\hline & \multicolumn{2}{|c|}{ Kurang } & \multicolumn{2}{|c|}{ Cukup } & \multicolumn{2}{|c|}{ Baik } & & \\
\hline & $\mathrm{n}$ & $\%$ & $\mathrm{n}$ & $\%$ & $\mathrm{n}$ & $\%$ & $\mathrm{n}$ & $\%$ \\
\hline Kurang dari 2 Tahun & 10 & 100,0 & 0 & 0,0 & 0 & 0,0 & 10 & 100,0 \\
\hline 3-5 Tahun & 7 & 58,3 & 4 & 33,3 & 1 & 8,3 & 15 & 100,0 \\
\hline Lebih dari 6 Tahun & 8 & 66,7 & 2 & 16,7 & 2 & 16,7 & 9 & 100,0 \\
\hline
\end{tabular}

Dimensi Civic virtue menunjukkan nilai paling tinggi dimiliki oleh pegawai dengan Masa Kerja selama kurang dari 2 tahun dengan kategori sangat kurang yaitu sebesar $60 \%$. Hasil penelitian ini sesuai dengan Greenberg dan Baron (2000) yang mengemukakan bahwa 
semakin lama masa kerja pegawai maka cenderung akan memiliki tindakan OCB yang lebih besar dibandingkan dengan pegawai dengan masa kerja yang baru dimulai. ${ }^{14} \mathrm{Hal}$ ini dikarenakan pegawai yang masih baru akan mengalami masa beradaptasi sehingga belum dapat menerapkan OCB tepatnya pada nilai Civic virtue terhadap pekerjaannya.

Sedangkan dimensi sportmanship menunjukkan nilai paling tinggi dimiliki oleh pegawai dengan Masa Kerja selama kurang dari 2 tahun dengan kategori cukup yaitu sebesar 90 $\%$. Hal ini sesuai dengan pernyataan dari Bukhori (2009) bahwa generasi yang sudah lama menapaki dunia pekerjaan pasti memiliki karakteristik mandiri dan loyal serta selalu ingin menciptakan keseimbangan dan kenyamanan dalam kehidupan sosial dengan dunia pekerjaan. $^{12}$ Dari pernyataan berikut dapat diketahui bahwa mayoritas pada pegawai dengan masa kerja lama akan lebih banyak menuntut jika keadaan organisasi kurang ideal karena ia akan mengutamakan kenyamanan. Sedangkan pegawai dengan masa kerja yang masih terhitung baru akan mudah memberikan toleransi terhadap keadaan yang kurang ideal dalam organisasi tanpa mengajukan keberatankeberatan karena masih dalam masa adaptasi pada berusaha menciptakan lingkungan kerja yang menyenangkan.

Dimensi Courtesy menunjukkan nilai paling tinggi dimiliki oleh pegawai dengan Masa Kerja selama 3-5 tahun dengan kategori kurang yaitu sebesar $75 \%$. Hal ini sesuai dengan pernyataan Kreitner dan Kinicki (2004) bahwa masa kerja yang lama akan membuat seorang pegawai merasa lebih betah atau cenderung mempunyai rasa keterikatan kerja dalam suatu organisasi atau perusahaan. ${ }^{15}$ Dengan begitu, akan mendorong untuk ia mencari rasa nyaman sesuai persepsinya. Dengan begitu, nilai courtesy kurang karena cenderung hanya memperhatikan kenyamanan dirinya sendiri tanpa memikirkan dan menghargai orang lain.

\section{SIMPULAN DAN SARAN}

Simpulan

Organizational Citizenship Behaviour pegawai di rumah sakit, sebagian besar berada pada kategori kurang. Pegawai yang berusia lebih dewasa cenderung memiliki OCB yang rendah. Pegawai yang memiliki masa kerja rendah cenderung memiliki OCB yang rendah.

\section{Saran}

Penting bagi manajemen rumah sakit untuk menguatkan hubungan antar pegawai melalui kegiatan gathering dan memaksimalkan potensi pegawai ketika menjalani training pegawai baru.

\section{REFERENSI}

1. Robbins, S.P. Perilaku Organisasi. Jakarta. Salemba Empat. 2006.

2. Organ, D.W., Pdsakoff P.M., MacKenzie S.B. Organizational Citizenship Behavior: Its Nature, Antecedents, and 
Consequences. USA. Sage Publications, Inc. 2006.

3. Mcdowell J. How Old I Feel Matters : Examining Age-Related Differences in Motives and Organizational Citizenship Behavior. 2015. 20-39.

4. Purnamie T. Peranan Organizational Citizenship Behavior (OCB). Jakarta. Mitra Wacana Media. 2014.

5. Akinbode G.A. Demographic and Dispositional Characteristic. 2011. 375404.

6. Gyekye S.A. \& Haybatollahi M. Organizational Citizenship Behaviour: An Empirical Investigation of The Impact of Age and Job Satisfaction on Ghanaian Industrial Workers. 2015.

7. Mahnaz M.A., Mehdi M., Jafar K.M. \& Abbolghasem P. The Effect of Demographic Characteristics on Organizational Citizenship Behavior in the Selected Teaching Hospitals in Tehran. African Journal of Business Management. 2013.

8. Singh A.K. \& Singh A. Career Stage and Organizational Citizenship Behaviour among Indian Managers. Journal of the Indian Academy Applied Psychology,
2010. 268-275.

9. Wijono S. Psikologi Industri dan Organisasi dalam Suatu Bidang Gerak Psikologi Sumber Daya Manusia. Jakarta: Kencana. 2014.

10. Griffith P. An Introduction to English Semantics and Pragmatics. Edinburgh University Press Ltd. 2006.

11. Sastrohadiwiryo B.S. Manajemen Tenaga Kerja Indonesia Pendekatan Administratif dan Operasional. Jakarta: PT. Bumi Aksara. 2005.

12. Bukhori I. Hubungan tingkat Pendidikan dan masa kerja terhadap prestasi kerja pegawai PT. PLN Area Pelayanan dan Jaringan Malang. Jurnal Manajemen. 2009. 163-172.

13. Rinda I. Stres Kerja dan Berbagai Faktor yang Berhubungan pada Pekerja Call Center PT. "X" di Jakarta. Majalah Kedokteran Indonesia. 2011. Volume 61, Nomor 1.

14. Greenberg J. \& Baron R.A. Behaviour in Organization. Upper Saddle River, New Jersey. Pretince Hall, Inc .2000.

15. Kreitner R. \& Kinicki A. Organizational behavior. Fifth edition. New York. McGraw Hill. 2004. 